Published in final edited form as:

Nat Sustain. 2018 September 14; 1(9): 477-485.

\title{
The environmental costs and benefits of high-yield farming
}

\author{
Andrew Balmford ${ }^{1, *}$, Tatsuya Amano ${ }^{1,2}$, Harriet Bartlett ${ }^{1}$, Dave Chadwick ${ }^{3}$, Adrian Collins ${ }^{4}$, \\ David Edwards $^{5}$, Rob Field ${ }^{6}$, Philip Garnsworthy ${ }^{7}$, Rhys Green ${ }^{1}$, Pete Smith ${ }^{8}$, Helen \\ Waters $^{1}$, Andrew Whitmore ${ }^{9}$, Donald M. Broom ${ }^{10}$, Julian Chara ${ }^{11}$, Tom Finch ${ }^{1,6}$, Emma \\ Garnett $^{1}$, Alfred Gathorne-Hardy ${ }^{12,13,14}$, Juan Hernandez-Medrano ${ }^{15}$, Mario Herrero ${ }^{16}$, \\ Fangyuan Hua $^{1}$, Agnieszka Latawiec ${ }^{17,18}$, Tom Misselbrook ${ }^{4}$, Ben Phalan ${ }^{1,19}$, Benno I. \\ Simmons ${ }^{1}$, Taro Takahashi ${ }^{4,20}$, James Vause ${ }^{21}$, Erasmus zu Ermgassen ${ }^{1}$, and Rowan \\ Eisner $^{1}$
}

${ }^{1}$ Conservation Science Group, Department of Zoology, Downing St, Cambridge CB2 3EJ, UK ${ }^{2}$ Centre for the Study of Existential Risk, University of Cambridge, 16 Mill Lane, Cambridge CB2 1SG, UK ${ }^{3}$ Environment Centre Wales, Deiniol Road, Bangor, Gwynedd LL57 2UW, UK ${ }^{4}$ Rothamsted Research, North Wyke, Okehampton EX20 2SB, UK ${ }^{5}$ Department of Animal and Plant Sciences, University of Sheffield, Western Bank, Sheffield, South Yorks S10 2TN, UK ${ }^{6}$ RSPB Centre for Conservation Science, The Royal Society for the Protection of Birds, The Lodge, Sandy, Bedfordshire SG19 2DL, UK ${ }^{7}$ School of Biosciences, Sutton Bonington Campus, University of Nottingham, Loughborough LE12 5RD, UK ${ }^{8}$ Institute of Biological and Environmental Sciences, University of Aberdeen, 23 St Machar Drive, Aberdeen AB24 3UU, UK ${ }^{9}$ Rothamsted Research, Harpenden, Hertfordshire AL5 2JQ, UK ${ }^{10}$ Department of Veterinary Medicine, University of Cambridge, Madingley Road, Cambridge CB3 OES, UK ${ }^{11} \mathrm{CIPAV}$, Centre for Research on Sustainable Agricultural Production Systems, Carrera 25 No 6-62, Cali 760042 , Colombia ${ }^{12}$ School of Geosciences, Crew Building, Kings Buildings, University of Edinburgh, Edinburgh EH9 3JN, UK ${ }^{13}$ Global Academy of Agriculture and Food Security, University of Edinburgh, Easter Bush Campus, Edinburgh EH25 9RG, UK ${ }^{14}$ Oxford India Centre for Sustainable Development, Somerville College, Oxford OX2 6HD, UK ${ }^{15}$ Faculty of Veterinary Medicine and Zootechny, National Autonomous University of Mexico, Av. Universidad 3000, Col. UNAM, CU, Coyoacan, Mexico City 04510, Mexico ${ }^{16}$ Commonwealth Scientific and Industrial Research Organisation, 306 Carmody Road, St Lucia, Qld 4067, Australia 17Pontifical Catholic University of Rio de Janeiro (PUC-Rio), Department of Geography and Environment, R. Marquês de São Vicente, 225 - Gávea, Rio de Janeiro - RJ, 22451-000, Brazil ${ }^{18}$ Institute of Agricultural Engineering and Informatics, Faculty of Production and Power Engineering, University of Agriculture in Kraków, Balicka 116B, 30-149 Kraków, Poland ${ }^{19}$ Universidade Federal da Bahia, Rua Barão de Jeremoabo, 147, Ondina, Salvador 40170-115, Bahia Brazil 20University of Bristol,

\footnotetext{
*Correspondence and requests for materials should be addressed to AB (apb12@cam.ac.uk), a.balmford@zoo.cam.ac.uk. Code availability. The $\mathrm{R}$ codes used for the analyses are available from the corresponding author upon request.

Data availability. The data that support the findings of this study are available from the corresponding author upon request. Author Contributions AB, TA, HB, DC, DE, RF, PG, RG, PS, HW, AW and RE designed the study and performed the research, DMB, AC, JC, TF, EG, AG-H, JHM, MH, FH, AL, TM, BP, BIS, TT, JV and EzE contributed and analysed data and results, and all authors contributed substantially to the analysis and interpretation of results and writing of the manuscript.

Author Information The authors declare no competing financial interests.
} 
British Veterinary School, Office Dolberry Building, Langford House, Langford, Bristol BS40 5DU, UK ${ }^{21}$ UN Environment World Conservation Monitoring Centre, 219 Huntingdon Road, Cambridge CB3 ODL, UK

\section{Abstract}

How we manage farming and food systems to meet rising demand is pivotal to the future of biodiversity. Extensive field data suggest impacts on wild populations would be greatly reduced through boosting yields on existing farmland so as to spare remaining natural habitats. High-yield farming raises other concerns because expressed per unit area it can generate high levels of externalities such as greenhouse gas (GHG) emissions and nutrient losses. However, such metrics underestimate the overall impacts of lower-yield systems, so here we develop a framework that instead compares externality and land costs per unit production. Applying this to diverse datasets describing the externalities of four major farm sectors reveals that, rather than involving trade-offs, the externality and land costs of alternative production systems can co-vary positively: per unit production, land-efficient systems often produce lower externalities. For GHG emissions these associations become more strongly positive once forgone sequestration is included. Our conclusions are limited: remarkably few studies report externalities alongside yields; many important externalities and farming systems are inadequately measured; and realising the environmental benefits of high-yield systems typically requires additional measures to limit farmland expansion. Yet our results nevertheless suggest that trade-offs among key cost metrics are not as ubiquitous as sometimes perceived.

\section{The biodiversity case for high-yield farming}

Agriculture already covers around $40 \%$ of Earth's ice- and desert-free land and is responsible for around two-thirds of freshwater withdrawals1. Its immense scale means it is already the largest source of threat to other species2, so how we cope with very marked increases in demand for farm products 3,4 will have profound consequences for the future of global biodiversity2,5. On the demand side, cutting food waste and excessive consumption of animal products are essential1,5-8. In terms of supply, farming at high yields (production per unit area) has considerable potential to restrict humanity's impacts on biodiversity. Detailed field data from five continents and almost 1800 species from birds to daisies9-14 reveals so many depend on native vegetation that for most the impacts of agriculture on their populations would be best limited by farming at high yields (production per unit area) alongside sparing large tracts of intact habitat. Provided it can be coupled with setting aside (or restoring) natural habitats15, lowering the land cost of agriculture thus appears central to addressing the extinction crisis2.

However, a key counterargument against this land-sparing approach is that there are many other environmental costs of agriculture besides the biodiversity displaced by the land it requires, such as greenhouse gas (GHG) and ammonia emissions, soil erosion, eutrophication, dispersal of harmful pesticides, and freshwater depletion5,7,16-18. Measured per unit area of farmland the production of such externalities is sometimes greater 
in high- than lower-yield farming systems 17,18, potentially weakening the case for land sparing. But while expressing externalities per unit area can help identify local-scale impacts19, it systematically underestimates the overall impact of lower-yield systems that occupy more land for the same level of production20. To be robust, assessments of externalities also need to include the off-site effects of management practices, such as crop production for supplementary feeding of livestock, or off-farm grazing for manure inputs to organic systems20-22.

\section{A novel framework for comparing system-wide costs}

In this paper we argue that comparisons of the overall impacts of contrasting agricultural systems should focus on the sum of externality generated per unit of production 10 (paralleling measures of emissions intensity in climate-change analyses). This approach has for the most part only been adopted for a relatively narrow set of agricultural products8,23 and farming systems (eg organic $v s$ conventional, glasshouse $v s$ open-field20,24). Here we develop a more general framework, and apply it to a diversity of data on some major farm sectors, farming systems and environmental externalities. Existing data are limited but nevertheless enable us to explore the utility of this new approach, test for broad patterns, and make an informed commentary on their significance for understanding the trade-offs and cobenefits of high- vs lower-yield systems.

Our framework involves plotting the environmental costs of producing a given quantity of a commodity against one another, across alternative production systems (as in Fig. 1). We focus on examining variation in some better-known externality costs in relation to land cost (i.e. 1/yield), because of the latter's fundamental importance as a proxy for impacts on biodiversity. However, the approach could be used to explore associations among any other costs for which data are available. Comparisons must be made across production systems that could, in principle, be substituted for one another, so they must be measured or modelled identically and in the same place or, if not, potential confounding effects of different methods, climate and soils must be removed statistically. If the idea that high-yield systems impose disproportionate externalities is true, we would expect plots of externality per unit production against land cost to show negative associations (Fig. 1a, blue symbols). However observed patterns may be more complex, and could reveal promising systems associated with low land cost and low externalities, or unpromising systems with high land and externality costs (Fig. 1b, green and red symbols respectively).

Our team of sector and externality specialists collated data for applying this framework to five major externalities (GHG emissions, water use, nitrogen [N], phosphorus [P] and soil losses) in four major sectors (Asian paddy rice, European wheat, Latin American beef, European dairy; Methods). We used both literature searches and consultation with experts to find paired yield and externality measurements for contrasting production systems in each sector. To be included, data had to be near-complete for a given externality - for example most major elements of GHG emissions or $\mathrm{N}$ losses had to be included, and if systems involved inputs (such as feeds or fertilisers) generated off-site we required data on the externality and land costs of their production. To limit confounding effects we narrowed our geographic scope within each sector (Supplementary Table 1), so that differences across 
systems could reasonably be attributed to farm practices rather than gross bioclimatic variation. Where co-products were generated we apportioned overall costs among products using economic allocation, but also investigated alternative allocation rules.

\section{Findings for four sectors}

Our first key result is that useable data are surprisingly scarce. Few studies measured paired externality and yield information, many reported externalities in substantially incomplete or irreconcilably divergent ways, and we could find no suitable data at all on some widely adopted practices. Nevertheless, we were able to obtain sufficient data to consider how externalities vary with land costs for nine out of 20 possible sector-externality combinations (Supplementary Table 1). The type of data available differed across these combinations (which we view as a useful test of the flexibility of our framework). For one combination the most extensive data we could find was from a long-term experiment at a single location. However because we were interested in generalities, where possible we used information from multiple studies - either field experiments or Life Cycle Assessments (LCAs) conducted across several sites - and used Generalised Linear Mixed Models (GLMMs) to correct for confounding method and site effects (Methods). Last, for two sectors we used process-based models parameterised for a fixed set of conditions representative of the region.

The data that we were able to obtain do not suggest that environmental costs are generally larger for farming systems with low land costs (i.e. high-yield systems; Fig. 2). If anything, positive associations - in which high-yield, land-efficient systems also have lower costs in other dimensions - appear more common. For Chinese paddy rice we found sufficient multisite experimental data to explore how two focal externalities vary with land cost across contrasting systems (Methods). GHG costs (Fig. 2a) showed negative associations with land cost across monoculture and rotational systems (assessed separately). Our GLMMs revealed that for both system types, greater application of organic $\mathrm{N}$ lowered land cost but increased emissions (probably because of feedstock effects on the methanogenic community25; Supplementary Table 2); in contrast there was little or no GHG penalty from boosting yield using inorganic $\mathrm{N}$ (arrows, Fig. 2a). A large volume of data on rice and water use showed weakly positive covariation in costs (Fig. 2b). GLMMs indicated that increasing application of inorganic $\mathrm{N}$ boosted yield26, and less irrigation lowered water use while incurring only a modest yield penalty27 (Supplementary Table 2). Sensitivity tests of the rice analyses had little impact on these patterns (Methods; Supplementary Fig. 2).

We found two useable datasets on European wheat, both from the UK (Methods). Our GLMMS of data from a three-site experiment varying the $\mathrm{N}$ fertilisation regime revealed a complex relationship between GHG and land costs (Fig. 2c; Supplementary Table 2), driven by divergent responses 28 to adding ammonium nitrate (which lowers land costs but increases embodied GHG emissions) and adding urea (which lowers land costs without increasing GHG emissions per unit production, but at the cost of increased ammonia volatilisation). A single-site experiment varying inorganic $\mathrm{N}$ treatments showed a non-linear relationship between land cost and $\mathrm{N}$ losses (Fig. 2d), with increasing $\mathrm{N}$ application 
lowering both costs until an apparent threshold, beyond which land cost decreased further but at the cost of greater $\mathrm{N}$ leaching (see also ref. 1).

In livestock systems, all data we could find showed positive covariation between land costs and externalities. For Latin American beef, we located coupled yield estimates only for GHG emissions, but here two different types of data (Methods) revealed a common pattern. Using GLMMs again to control for potentially confounding study and site effects, we found that across multiple LCAs, pasture systems with greater land demands also generated greater emissions (Fig. 2e), with both land and GHG costs reduced by pasture improvements (using $\mathrm{N}$ fertilization or legumes). This pattern across contrasting pasture systems was confirmed by running RUMINANT29 (Fig. 2f), a process-based model which also identified relatively low land and GHG costs for a series of silvopasture and feedlot-finishing systems (for which comparable LCA data were unavailable).

For European dairy, process-based modelling of three conventional and two organic systems, parameterised for the UK, enabled us to estimate four different externalities alongside yield (Methods). This showed that conventional systems - especially those using less grazing and more concentrates - had substantially lower land and also GHG costs (Fig. 2g), in part because concentrates reduce $\mathrm{CH}_{4}$ emissions from fibre digestion30. Systems with greater use of concentrates (which have less rumen-degradable protein than grass31) also showed lower losses of N, P and soil per unit production (Fig. 2h,i,j). These broad patterns persisted when we used protein production rather than economic value to allocate costs to co-products (Methods; Supplementary Fig. 2).

\section{Incorporating land use}

As a final analysis we examined the additional externalities resulting from the different land requirements of contrasting systems. To generate the same quantity of agricultural product, low-yield systems require more land, allowing less to be retained or restored as natural habitat. This is in turn likely to increase GHG emissions and soil loss, and alter hydrology though we could only find enough data to explore the first of these effects. For each sector we supplemented our direct GHG figures for each system with estimates of GHG consequences of their land use following IPCC methods 32 to calculate the sequestration potential of a hectare not used for farming and instead allowed to revert to climax vegetation (Methods). Results (Fig. 3) showed that these GHG opportunity costs of agriculture were typically greater than the emissions from farming activities themselves and, when added to them, in every sector generated strongly positive across-system associations between overall GHG cost and land cost. These patterns were maintained in sensitivity tests where we halved recovery rates or assumed half of the area potentially freed from farming was retained under agriculture (Methods; Supplementary Fig. 3). These findings thus confirm recent suggestions33,34 that high-yield farming has the potential, provided land not needed for production is largely used for carbon sequestration, to make a substantial contribution to mitigating climate change. 


\section{Conclusions, caveats, and knowledge gaps}

This study was conceived as an exploration of whether high-yield systems - central to the idea of sparing land for nature in the face of enormous human demand for farm products typically impose greater negative externalities than alternative approaches. Our results support three conclusions. First, useful data are worryingly limited. We considered only four relatively well-studied sectors and a narrow set of externalities - not including important impacts such as soil health or the effects of pesticide exposure on human health20. Even then we found studies reporting yield-linked estimates of externalities scarce, with many widely adopted or promising practices within these sectors undocumented. We were not able to examine complex agricultural systems (such as mixed farming, or agroforestry) which might have relatively low externalities. Relevant data on many significant developing-world farm sectors (such as cassava or dryland cereal production in Africa) also appear very limited. Given that a multi-dimensional understanding of the environmental effects of alternative production systems is integral to delivering sustainable intensification, more field measurements linking yield with a broader suite of externalities across a much wider range of practices and sectors are urgently needed.

Second, the available data on the sector-externality combinations we considered do not suggest that negative associations between land cost and other environmental costs of farming are typical ( $c f$ Fig. 1a). Many low-yield systems impose high costs in other ways too and, although certain yield-improving practices have undesirable impacts (e.g. organic fertilisation of paddy rice increasing $\mathrm{CH}_{4}$ emissions; see also ref. 1), other practices appear capable of reducing several costs simultaneously (see also refs 1,8,24,35,36). High (but not excessive) application of inorganic $\mathrm{N}$, for example, can lower land take of Chinese rice production without incurring GHG or water-use penalties. Similarly, in Brazilian beef production adopting better pasture management, semi-intensive silvopasture and feedlotfinishing can all boost yields alongside lowering GHG emissions. It is worth noting that although most systems we examined are relatively high-yielding, other recent work suggests that positive associations ( $c f$ trade-offs) among environmental and land costs may if anything be more likely in lower-yielding systems 1 .

Third, pursuing promising high-yield systems is clearly not the same as encouraging business-as-usual industrial agriculture. Some high-yield practices we did not examine, such as the heavy use of pesticides in much tropical fruit cultivation37, are likely to increase externality costs per unit production. Of the high-yield practices we did investigate some, such as applying fossil-fuel-derived ammonium nitrate to UK wheat, impose disproportionately high environmental costs. Others that seem favourable in terms of our focal externalities incur other costs, such as high $\mathrm{NH}_{3}$ emissions from using urea on wheat 28 , and management regimes that reduce costs in one geographic setting may not do so in others1. Much work characterising existing systems and designing new ones is thus needed. We suggest our framework can serve as a device for identifying existing yieldenhancing systems which also lower other environmental costs - and perhaps more importantly, for benchmarking the environmental performance of promising new technologies and practices. 
We close by stressing that for high-yield systems to generate any environmental benefits they must be coupled with efforts to reduce rebound effects. Several plausible mechanisms for limiting these by explicitly linking yield growth to improved environmental performance have been identified - including strict land-use zoning; strategic deployment of yieldenhancing loans, expertise or infrastructure; conditional access to markets; and restructured rural subsidies15. Without such linkages, systems which perform well per unit production may nevertheless cause net environmental harm through higher profits or lower prices stimulating land conversion $38-40$, and damage human health by encouraging overconsumption of cheap, calorie-rich but nutrient-deficient foods 41,42 . If promising highyield strategies are to help solve rather than exacerbate society's challenges, yield increases instead need to be combined with far-reaching demand-side interventions1,6,41 and directly linked with effective measures to constrain agricultural expansion 15 .

\section{Methods}

\section{Focal sectors and externalities}

We focused on 4 globally significant farm sectors (Asian paddy rice, European wheat, Latin American beef, European dairy, accounting for $90 \%, 33 \%, 23 \%$ and $53 \%$ of global output of these products43) and 5 major externalities (greenhouse gas [GHG] emissions, water use, nitrogen $[\mathrm{N}]$, phosphorus $[\mathrm{P}]$ and soil losses). We chose these sector-externality combinations because preliminary work suggested they were characterised quantitatively relatively often, using diverse approaches (single-site experiments, multi-site experiments, Life Cycle Assessments [LCAs] and process-based models), enabling us to explore the generality of our framework. We then searched the literature and consulted experts to obtain paired yield and externality estimates of alternative production systems in each sector, narrowing our geographic scope so that differences in system performance could be reasonably attributed to management practices (rather than gross variation in bioclimate or soils). Our analyses have rarely been attempted previously and have complex data requirements, so we could not adopt standard procedures developed for systematic reviews on topics where many studies have attempted to answer the same research question.

This process generated data on $\geq 5$ contrasting production systems for 9 out of 20 possible sector-externality combinations (Supplementary Table 1): Chinese rice-GHG emissions (from multi-site experiments); Chinese rice-water use (multi-site experiments); UK wheatGHG emissions (a multi-site experiment); UK wheat-N emissions (a single-site experiment); Brazilian beef-GHG emissions (both LCA data and process-based models); and UK dairyGHG emissions, and N, P and soil losses (process-based models). Water use in the wheat and most of the beef systems examined was limited and so not explored further. We could not find sufficient paired yield-externality estimates for the 9 remaining sector-externality combinations.

The land and externality costs of each system were then expressed as total area used per unit production (i.e. 1/yield) and total amount of externality generated per unit production. All estimates included the area used and externalities generated in producing externally-derived inputs (such as feed or fertilisers). For analytical tractability, as in other recent studies1,24 we treat impacts occurring at different times and places as being additive. Occasional gaps in 
estimates for a system were filled using standard values from IPCC or other sources, or information from study authors or comparable systems (details below). Where experiments or LCAs were conducted at multiple sites, we built Generalised Linear Mixed Models (GLMMs) in the package lme444 in R version 3.3.145 to identify effects of specific management practices on land and externality cost estimates adjusted for potentially confounding biophysical and methodological effects. To illustrate the effects of statistically significant management variables (those whose $95 \%$ confidence intervals did not overlap zero; shown in bold in Supplementary Table 2) we estimated land and externality costs at the observed minimum and maximum values (for continuous management variables) or with the reference category and the category that showed the maximum effect size (for categorical variables), while keeping other variables constant; we then linked these points as arrows on our externality cost/land cost plots (Fig. 2 and Supplementary Figs. 1 and 2, with arrows displaced horizontally and/or vertically for increased visibility). Where systems generated significant co-products (wheat and rapeseed from rotational rice, beef from dairy) we allocated land and externality costs to the focal product in proportion to its relative contribution to the gross monetary value of production per unit area of farmland (from focal and co-product combined) 46 .

\section{Rice and GHG emissions}

Systematic searching of Scopus for experimental studies reporting both yields and emissions of Chinese paddy rice systems identified 17 recently published studies47-63 containing 140 paired yield-emissions estimates for different systems (after within-year replicates of a system were averaged). To limit confounding effects we analysed separately the data from monoculture systems from southern provinces ( 2 rice crops per year; 5 studies, 60 estimates) and rotational systems from more northerly provinces (1 rice and 1 wheat or rape crop per year; 12 studies, 80 estimates). The studies documented the effects of variation in tillage (yes/no), application rates of inorganic and organic $\mathrm{N}$, and (for rotational systems only) irrigation regime (continuous flooding $v s$ episodic midseason drainage). There were insufficient data to examine effects of seedling density, crop variety, organic practices, biochar application, use of groundcover to lower emissions, $\mathrm{N}$ fertiliser type, or $\mathrm{K}$ or $\mathrm{P}$ fertilisation.

Land cost estimates were expressed in ha-years/tonne rice grain (i.e. the inverse of annual production per hectare farmed). GHG costs were expressed in tonnes $\mathrm{CO}_{2} \mathrm{eq} /$ tonne rice grain, and included $\mathrm{CH}_{4}$ and $\mathrm{N}_{2} \mathrm{O}$ emissions for growing and fallow seasons (with the latter where necessary based on mean values from refs 47-49,64), and embodied emissions from $\mathrm{N}$ fertiliser production (Yara emissions database; F. Brendrup, pers. comm.). We were unable to include emissions from producing manure or $\mathrm{K}$ or $\mathrm{P}$ fertiliser, or from farm machinery. For rotational systems we adjusted the land and GHG costs of rice production downwards by multiplying them by the proportional contribution of rice to the gross monetary value of production per unit area of farmland from rice and co-product combined (using mean post-2000 prices from ref. 43).

We next built GLMMs predicting variation in our estimates of land cost and GHG cost, for the monoculture and rotational datasets in turn. Management practices assessed as predictors 
were tillage regime (binary), application rates of organic $\mathrm{N}$ and of inorganic $\mathrm{N}$, and irrigation regime (binary; rotational systems only). Study site was included as a random effect. For all systems we adjusted for biophysical and methodological differences across sites using the first two components from a Principal Component Analysis of site scores for 14 variables: annual precipitation, precipitation during the driest and wettest quarters, annual mean temperature, mean temperatures during the warmest and coldest quarters, maximum temperature during the warmest month, mean monthly solar radiation, latitude, longitude, soil organic carbon content, plot size, replicates per estimate, and start year (with all climate data taken from refs 65,66$)$. PCs 1 and 2 together explained $82.3 \%$ and $76.2 \%$ of the variance in these variables for monoculture and rotational systems, respectively. Soil $\mathrm{pH}$ and $(\text { soil } \mathrm{pH})^{2}$ were also assessed as additional predictors. For the monoculture models tolerance values were all $>0.4$ (indicating an absence of multicollinearity) except for the $\mathrm{pH}$ terms (both $<0.1$ ), which we therefore removed. For the rotational models all tolerance values indicated an absence of multicollinearity, but (soil $\mathrm{pH})^{2}$ was removed because AICc values indicated model fit was no better than using soil pH alone. Final models (Supplementary Table 2) were then used to plot site-adjusted land and GHG costs (as points) and statistically significant management effects (as arrows) in Fig. 2a. We also tested the effect of allocating land and GHG costs in rotational systems based on the relative energy content of rice and co-products67 ( $c f$ relative contribution to gross monetary value; Supplementary Fig. 2).

We adopted similar though simpler approaches for the next two sector-externality combinations, which again used data from multi-site experiments.

\section{Rice and water use}

A systematic search on Scopus yielded 15 recent studies57,58,64,68-79 meeting our criteria containing 123 paired estimates describing the effects of variation in inorganic $\mathrm{N}$ application rate and irrigation regime on land and water costs of Chinese paddy rice. We analysed monoculture and rotational systems together but considered water use solely for periods of rice production. Land cost was expressed in ha-years/tonne rice grain, and water cost in $\mathrm{m}^{3} /$ tonne rice grain (excluding rainfall). We adjusted these estimates for site effects in GLMMs of variation in land and water costs using as predictors the application rate of inorganic N, and irrigation regime (a 6-level factor: continuous flooding, continuous flooding with drainage, alternate wetting and drying, controlled irrigation, mulches or plastic films, and long periods of dry soil), while accounting for the effect of study site as a random effect. Tolerance values were all $>0.7$. Final models (Supplementary Table 2 ) were then used to plot site-adjusted land and water costs (points) and significant management effects (arrows) in Fig. 2b. Almost all sources reported data on only one rice season per year, but one study68 included separate estimates for early- and late-season rice, so we checked the robustness of our findings by re-running the analysis without the early-season data from this study (Supplementary Fig. 2).

\section{Wheat and GHG emissions}

The Agricultural Greenhouse Gas Inventory Research Platform80-83 provided 96 paired measures of variation in yield and $\mathrm{N}_{2} \mathrm{O}$ emissions in response to experimental changes in $\mathrm{N}$ fertiliser application rate and type. We expanded the emissions profile to include embodied 
emissions from $\mathrm{N}$ fertiliser production (from the Yara emissions database; F. Brendrup, pers. comm.). We derived land costs in ha-years/tonne wheat (at $85 \%$ dry matter) and GHG costs in tonnes $\mathrm{CO}_{2} \mathrm{eq} /$ tonne wheat. Experiments were run in 3 regions, so to adjust for site effects we built GLMMs of variation in land and GHG costs fitting study region as a random effect and using the application rates of ammonium nitrate, urea and dicyandiamide (a nitrification inhibitor) as predictors. Tolerance values were all $>0.7$. Adjusted land and GHG cost estimates from the final models (Supplementary Table 2) are plotted in Fig. 2c, with arrows showing statistically significant management practices.

\section{Wheat and $\mathbf{N}$ losses}

We assessed this sector-externality combination using data from Rothamsted's long-term Broadbalk wheat experiment, which investigates the effects of inorganic $\mathrm{N}$ application rates on yields of winter wheat. During the 1990s changes in field drainage enabled the measurement (alongside yield) of plot-specific leaching losses of nitrate84. Mean land and $\mathrm{N}$ costs - expressed in ha-years/tonne wheat (at $85 \%$ dry matter) and $\mathrm{kg} \mathrm{N}$ leached/tonne wheat, respectively - were averaged across 8 seasons (thus smoothing-out rainfall effects), for each of 7 levels of $\mathrm{N}$ application (from $0-288 \mathrm{~kg} \mathrm{~N}$ [as ammonium nitrate]/ha-y; details in Fig. 2 legend). Results are plotted in Fig. 2d.

\section{Beef and GHG emissions}

Two types of data were available for this sector-externality combination, enabling us to compare findings across assessment techniques. First we examined all published LCAs of Brazilian beef production85-92. Supplementing this with a bioclimatically comparable dataset from tropical Mexico (R. Olea-Perez, pers. comm.) yielded 33 paired yieldemissions estimates for contrasting production systems. These varied in whether they used improved pasture, supplementary feeding, or improved breeds (which if unreported we inferred from age at first calving, and mortality and conception rates). There were insufficient LCA data to examine the effects of feedlots, silvopasture, or rotational grazing. Land costs were calculated in ha-years/tonne Carcass Weight [CW], incorporating land used to grow feed, and assuming a dressing percentage of 50\%93. GHG costs were derived in tonnes $\mathrm{CO}_{2} \mathrm{eq}$ /tonne $\mathrm{CW}$, including enteric $\mathrm{CH}_{4}$ emissions, $\mathrm{CH}_{4}$ and $\mathrm{N}_{2} \mathrm{O}$ emissions from manure, $\mathrm{N}_{2} \mathrm{O}$ emissions from managed pasture, emissions from supplementary feed production (where necessary using values from ref. 86), and embodied GHG emissions from $\mathrm{N}, \mathrm{P}$ and $\mathrm{K}$ fertiliser production. There were too few data to include $\mathrm{CO}_{2}$ emissions from lime application or farm machinery. Milk production was not a significant co-product. To control for site effects we built GLMMs of variation in land and GHG costs using site as a random effect and use of improved pasture, supplementary feeding and improved breeds (each a binary factor) as predictors. Tolerance values were all $>0.8$. Adjusted land and GHG cost estimates from the final models (Supplementary Table 2) are plotted in Fig. 2e, with arrows describing statistically significant management practices.

For comparison we derived an equivalent GHG cost $v s$ land cost plot (Fig. 2f) using a process-based model of beef production. RUMINANT29 is an IPCC tier 3 digestion and metabolism model which uses stoichiometric equations to estimate production of meat, manure $\mathrm{N}$ and enteric methane for any given pasture quality, supplementary feed quantity 
and type, cattle breed, and region. We used plausible combinations of these settings (Supplementary Table 3) and corresponding values of feed and forage protein, digestibility and carbohydrate content (judged representative of the Brazilian beef sector by $\mathrm{MH}$ ) to derive yield and emissions estimates for 86 contrasting pasture systems. To extend beyond the scope of the LCA analyses we also modelled 50 silvopasture systems by boosting feed quality to simulate access to Leucaena, and 8 feedlot-finishing systems by incorporating an 83-120 day feedlot phase when animals received high-quality mixed ration. For each system we included the whole herd, after determining the ratio of fattening:breeding animals using the DYNMOD demographic projection tool94, based on system-specific reproductive performance parameters and animal growth rates (reflecting pasture quality and management; Supplementary Table 3). Breeding animals experienced the same conditions as fattening animals (except that in pasture and silvopasture they received no supplementary feed). Stocking rates were set to sustainable carrying capacity for pasture and silvopasture, and 201 animals/ha for feedlots (DB pers. obs.). Yields were converted to land cost in hayears/tonne $\mathrm{CW}$, including the area of feedlots and land required to grow feed (using feed composition and yield data from refs 43,85). RUMINANT emissions estimates were supplemented with estimates of manure $\mathrm{CH}_{4}, \mathrm{CO}_{2}$ and $\mathrm{N}_{2} \mathrm{O}$ emissions from feed production, and $\mathrm{N}_{2} \mathrm{O}$ emissions from pasture fertilisation (from refs 32,85 ). Carbon sequestration by vegetation could not be included, so we probably overestimate net GHG emissions from silvopasture95. All emissions were converted to $\mathrm{CO}_{2}$ eq units (using conversion factors from refs 32,85 and feedlot manure distribution from ref. 96) and expressed in tonnes $\mathrm{CO}_{2} \mathrm{eq} /$ tonne $\mathrm{CW}$.

\section{Dairy and four externalities}

We also used process-based models to investigate how GHG emissions and N, P and soil losses varied with land cost across 5 dairy systems representative of UK practices (Supplementary Table 4; Figs. 2g-j). We modelled three conventional systems with animals accessing grazing for 270, 180 and 0 days/year, and two organic systems with grazing access for 270 and 200 days/year. Model farms were assigned rainfall and soil characteristics based on frequency distributions of these parameters for real farms of each type, with structural and management data (e.g. ratios of livestock categories and ages, $\mathrm{N}$ and $\mathrm{P}$ excretion rates) based on the models of refs 31,97,98. Manure management was based on representative variations of the "manure management continuum"99 (Supplementary Table 4). Physical performance data (annual milk yield, concentrate feed input, replacement rate and stocking rate) were obtained from the AHDB Dairy database (M. Topliff pers. comm.) for conventional systems and from DEFRA100 for organic systems.

Yields were converted to land cost in ha-years/tonne Energy-Corrected Milk (ECM), including land required to grow feed (from refs 101,102, with yield penalties for organic production from ref. 103). Because $57 \%$ of global beef production originates from the dairy sector104, we adjusted land costs downwards by multiplying them by the proportional contribution of milk to the gross monetary value of production per unit area of farmland from milk and beef combined (using prices from the AHDB Dairy database (M. Topliff pers. comm.)). 
GHG cost estimates for each system comprised $\mathrm{CH}_{4}$ emissions from enteric fermentation (based on ref. 31), $\mathrm{CH}_{4}$ and $\mathrm{N}_{2} \mathrm{O}$ emissions from manure management (following refs 32 and 105), emissions from $\mathrm{N}$ fertiliser applications to pasture (from refs 106,107), and from feed production (from ref. 108). Emissions from farm machinery and buildings were not included. Emissions were then summed and expressed in tonnes $\mathrm{CO}_{2} \mathrm{eq} /$ tonne ECM. Nitrate losses of each system were derived from the National Environment Agricultural PollutionNitrate (NEAP-N) model109,110, whilst P and soil losses were estimated using the Phosphorus and Sediment Yield CHaracterisation In Catchments (PSYCHIC) model111,98. These last three costs were expressed in kg/tonne ECM and (as with land costs) downscaled by allocating a portion of them to beef co-products, based on milk and beef prices. Finally, to check the effect of this allocation rule we re-ran each analysis instead allocating costs using the relative protein content of milk and beef (from ref. 104; Supplementary Fig. 2).

\section{GHG opportunity costs of land farmed}

Alongside the GHG emissions generated by agricultural activities themselves (analysed above), farming typically carries an additional GHG cost. Wherever the carbon content of farmed land is less than that of the natural habitat that could replace it if agriculture ceased, farming imposes an opportunity cost of sequestration forgone112, whose magnitude increases with the area under production (and hence with the land cost of the system). We quantified this GHG cost using the forgone sequestration method, whereby retaining the current land use is assumed to prevent the sequestration in soils and biomass that would occur if the land was allowed to revert to climax vegetation (see details in Supplementary Table 5).

For each forgone transition, values for annual biomass accrual ( $\_20$ years) were taken from Table 4.9 of ref. 32, assuming that the climax vegetation for UK wheat and dairy was "temperate oceanic forest (Europe)", for Chinese rice it was "tropical moist deciduous forest (Asia, continental)", and for Brazilian beef it was "tropical moist deciduous forest (South America)". The carbon content of all biomass was assumed to be $47 \%$ of dry matter (ref. 32 Table 4.3).

Changes in soil carbon values were taken from the relevant mean percentage change in soil organic carbon values for each land conversion from a global meta-analysis113. For UK wheat and Chinese rice we used values for conversion of cropland to woodland; for UK dairy and Brazilian beef we used conversion of grassland to woodland for grazing land and conversion of cropland to woodland for land used to grow feed. Initial soil carbon values were taken from Table 2.3 of ref. 32. We assumed the soils for UK wheat were "cold temperate, moist, high activity soils", for Chinese rice they were "tropical, wet, low activity soils", for UK dairy they were "cold temperate, moist, high activity soils" for grazing land and for producing imported feed they were "subtropical humid, LAC soils" (South America), and for Brazilian beef for both grazing and feed production they were "tropical, moist, low activity soils". In each case the relevant percentage change in soil organic carbon was multiplied by the initial soil carbon stock to calculate an absolute change, which, following IPCC guidelines32, we assumed took 20 years. 
Total annual forgone sequestration was then estimated by adding this annual change in soil organic carbon and the annual accrual of biomass carbon under reversion to climax vegetation. We assumed (as in ref. 34) that each 1ha reduction in land cost results in 1ha of recovering habitat. As above, our land cost estimates included land needed to produce externally-derived inputs, and (for rotational rice and dairy) were adjusted downwards based on the value of co-products. These GHG opportunity costs were then added to the direct GHG emissions estimates of each system, and the summed values plotted against land cost (Fig. 3).

As a sensitivity test of our key assumptions we re-ran these analyses assuming that carbon recovery rates are halved, or that (because of rebound or similar effects38-40) half of the area potentially freed from farming is retained under agriculture. These two changes to our assumptions have numerically identical effects, shown in Supplementary Fig. 3. Note that our recovery-based estimates of the GHG costs that farming imposes through land use are conservative, in that they are roughly $30-50 \%$ of those obtained from calculating GHG emissions from natural habitat clearance (annualised, for consistency with the recovery method, over 20 harvests; data not shown).

\section{Supplementary Material}

Refer to Web version on PubMed Central for supplementary material.

\section{Acknowledgements}

We are grateful for funding from the Cambridge Conservation Initiative Collaborative Fund and Arcadia, the Grantham Foundation for the Protection of the Environment, the Kenneth Miller Trust the UK-China Virtual Joint Centre for Agricultural Nitrogen (CINAg, BB/N013468/1, financed by the Newton Fund via BBSRC and NERC), BBSRC (BBS/E/C/000I0330), DEVIL (NE/M021327/1), U-GRASS (NE/M016900/1), Soils-R-GRREAT (NE/ P019455/1), N-Circle (BB/N013484/1), BBSRC Soil to Nutrition (S2N) strategic programme (BBS/E/C/000I0330), UNAM-PAPIIT (IV200715), the Belmont Forum/FACEE-JPI (NE/M021327/1 'DEVIL'), and the Cambridge Earth System Science NERC DTP (NE/L002507/1); AB is supported by a Royal Society Wolfson Research Merit award. Rice and wheat icons made by Freepik from www.flaticom.com. We thank Frank Brendrup, Emma Caton, Achim Dobermann, Thiago Jose Florindo, Ellen Fonte, Ottoline Leyser, Andre Mazzetto, Jemima Murthwaite, Farahnaz Pashaei Kamali, Rafael Olea-Perez, Stephen Ramsden, Claudio Ruviaro, Jonathan Storkey, Bernardo Strassburg, Mark Topliff, Joao Nunes Vieira da Silva, David Williams, Xiaoyuan Yan and Yusheng Zhang for advice, data or analysis, and to Kate Willott for much practical support.

\section{References}

1. Poore J, Nemecek T. Reducing food's environmental impacts through producers and consumers. Science. 2018; 360:987-992. [PubMed: 29853680]

2. Green RE, Cornell SJ, Scharlemann JPW, Balmford A. Farming and the fate of wild nature. Science. 2005; 307:550-555. [PubMed: 15618485]

3. Tilman D, Balzer C, Hill J, Befort BL. Global food demand and the sustainable intensification of agriculture. Proc Natl Acad Sci U S A. 2011; 108:20260-20264. [PubMed: 22106295]

4. Hunter MC, Smith RG, Schipanski ME, Atwood LW, Mortensen DA. Agriculture in 2050: recalibrating targets for sustainable intensification. Bioscience. 2017; 67:386-391.

5. Godfray HCJ, et al. Food security: the challenge of feeding 9 billion people. Science. 2010; 327:812-818. [PubMed: 20110467]

6. Bajželj B, et al. Importance of food-demand management for climate mitigation. Nat Clim Chang. 2014; 4:924-929.

7. Foley JA, et al. Solutions for a cultivated planet. Nature. 2011; 478:337-342. [PubMed: 21993620] 
8. Ripple WJ, et al. Ruminants, climate change and climate policy. Nat Clim Chang. 2014; 4:2-5.

9. Phalan B, Onial M, Balmford A, Green RE. Reconciling food production and biodiversity conservation: land sharing and land sparing compared. Science. 2011; 333:1289-1291. [PubMed: 21885781]

10. Balmford A, Green R, Phalan B. Land for food \& land for nature? Daedalus. 2015; 144:57-75.

11. Hulme MF, et al. Conserving the birds of Uganda's banana-coffee arc: land sparing and land sharing compared. PLoS One. 2013; 8:e54597. [PubMed: 23390501]

12. Kamp J, et al. Agricultural development and the conservation of avian biodiversity on the Eurasian steppes: a comparison of land-sparing and land-sharing approaches. J Appl Ecol. 2015; 52:15781587.

13. Dotta G, Phalan B, Silva TW, Green R, Balmford A. Assessing strategies to reconcile agriculture and bird conservation in the temperate grasslands of South America: grasslands conservation and agriculture. Conserv Biol. 2016; 30:618-627. [PubMed: 26400720]

14. Williams DR, et al. Land-use strategies to balance livestock production, biodiversity conservation and carbon storage in Yucatán, Mexico. Glob Chang Biol. 2017; 23:5260-5272. [PubMed: 28614629]

15. Phalan B, et al. How can higher-yield farming help to spare nature? Science. 2016; 351:450-451. [PubMed: 26823413]

16. Pretty J. Agricultural sustainability: concepts, principles and evidence. Philos Trans R Soc Lond B Biol Sci. 2008; 363:447-465. [PubMed: 17652074]

17. Matson PA, Parton WJ, Power AG, Swift MJ. Agricultural intensification and ecosystem properties. Science. 1997; 277:504-509. [PubMed: 20662149]

18. Tilman D, Cassman KG, Matson PA, Naylor R, Polasky S. Agricultural sustainability and intensive production practices. Nature. 2002; 418:671-677. [PubMed: 12167873]

19. Didham RK, et al. Agricultural intensification exacerbates spillover effects on soil biogeochemistry in adjacent forest remnants. PLoS One. 2015; 10:e0116474. [PubMed: 25575017]

20. Seufert V, Ramankutty N. Many shades of gray - the context-dependent performance of organic agriculture. Sci Adv. 2017; 3:e1602638. [PubMed: 28345054]

21. Kirchmann H, Bergström L, Kätterer T, Andrén O, Andersson R. Organic Crop Production Ambitions and Limitations. Kirchmann H, Bergström L, editorsSpringer; Dordrecht, The Netherlands: 2008. 39-72.

22. Madhusudan MD. The global village: linkages between international coffee markets and grazing by livestock in a South Indian wildlife reserve. Conserv Biol. 2005; 19:411-420.

23. Nijdam D, Rood T, Westhoek H. The price of protein: review of land use and carbon footprints from life cycle assessments of animal food products and their substitutes. Food Policy. 2012; 37:760-770.

24. Clark M, Tilman D. Comparative analysis of environmental impacts of agricultural production systems, agricultural input efficiency, and food choice. Environ Res Lett. 2017; 1264016.

25. Yan X, Yagi K, Akiyama H, Akimoto H. Statistical analysis of the major variables controlling methane emission from rice fields. Glob Chang Biol. 2005; 11:1131-1141.

26. Pittelkow CM, Adviento-Borbe MA, van Kessel C, Hill JE, Linquist BA. Optimizing rice yields while minimizing yield-scaled global warming potential. Glob Chang Biol. 2014; 20:1382-1393. [PubMed: 24115565]

27. Carrijo DR, Lundy ME, Linquist BA. Rice yields and water use under alternate wetting and drying irrigation: a meta-analysis. F Crop Res. 2017; 203:173-180.

28. Smith KA, et al. The effect of $\mathrm{N}$ fertilizer forms on nitrous oxide emissions from UK arable land and grassland. Nutr Cycl Agroecosystems. 2012; 93:127-149.

29. Herrero M, et al. Biomass use, production, feed efficiencies, and greenhouse gas emissions from global livestock systems. Proc Natl Acad Sci U S A. 2013; 110:20888-20893. [PubMed: 24344273]

30. Beauchemin K, McAllister TA, McGinn SM. Dietary mitigation of enteric methane from cattle. CAB Rev Perspect Agric Vet Sci Nutr Nat Resour. 2009; 4:1-18. 
31. Wilkinson JM, Garnsworthy PC. Dietary options to reduce the environmental impact of milk production. J Agric Sci. 2017; 155:334-347.

32. Eggleston HS, Buendia L, Miwa K, Ngara T, Tanabe K, editorsIPCC. 2006 IPCC Guidelines for National Greenhouse Gas Inventories, Prepared by the National Greenhouse Gas Inventories Programme. IGES; Hayama: 2006.

33. Gilroy JJ, et al. Optimizing carbon storage and biodiversity protection in tropical agricultural landscapes. Glob Chang Biol. 2014; 20:2162-2172. [PubMed: 24764180]

34. Lamb A, et al. The potential for land sparing to offset greenhouse gas emissions from agriculture. Nat Clim Chang. 2016; 6:488-492.

35. Cui Z, et al. Pursuing sustainable productivity with millions of smallholder farmers. Nature. 2018; 555:363-366. [PubMed: 29513654]

36. Notarnicola B, et al. The role of life cycle assessment in supporting sustainable agri-food systems: a review of the challenges. J Clean Prod. 2017; 140:399-409.

37. Bravo V, et al. Monitoring pesticide use and associated health hazards in Central America. Int $\mathbf{J}$ Occup Environ Heal J Int J Occup Environ Heal. 2011; 173:1077-3525.

38. Lambin EF, Meyfroidt P. Global land use change, economic globalization, and the looming land scarcity. Proc Natl Acad Sci U S A. 2011; 108:3465-3472. [PubMed: 21321211]

39. Ewers RM, Scharlemann JPW, Balmford A, Green RE. Do increases in agricultural yield spare land for nature? Glob Chang Biol. 2009; 15:1716-1726.

40. Byerlee D, Stevenson J, Villoria N. Does intensification slow crop land expansion or encourage deforestation? Glob Food Sec. 2014; 3:92-98.

41. Tilman D, Clark M. Global diets link environmental sustainability and human health. Nature. 2014; 515:518-522. [PubMed: 25383533]

42. Yang Q, et al. Added sugar intake and cardiovascular diseases mortality among US adults. JAMA Intern Med. 2014; 174:516. [PubMed: 24493081]

43. FAO. FAOSTAT: Food and Agriculture Data. Food and Agriculture Organization of the Uniated Nations; Rome: 2017. http://fao.org/faostat/

44. Bates D, Mächler M, Bolker B, Walker S. Fitting linear mixed-effects models using lme4. J Stat Softw. 2015; 67:1-48.

45. R Core Team. R: A Language and Environment for Statistical Computing. R Foundation for Statistical Computing; Vienna, Austria: 2016. https://www.r-project.org/

46. Guinée JB, Heijungs R, Huppes G. Economic allocation: examples and derived decision tree. Int J Life Cycle Assess. 2004; 9:23-33.

47. Shang Q, et al. Net annual global warming potential and greenhouse gas intensity in Chinese double rice-cropping systems: a 3-year field measurement in long-term fertilizer experiments. Glob Chang Biol. 2011; 17:2196-2210.

48. Liu Y, et al. Net global warming potential and greenhouse gas intensity from the double rice system with integrated soil-crop system management: a three-year field study. Atmos Environ. 2015; 116:92-101.

49. Chen Z, Chen F, Zhang H, Liu S. Effects of nitrogen application rates on net annual global warming potential and greenhouse gas intensity in double-rice cropping systems of the Southern China. Environ Sci Pollut Res Int. 2016; 23:24781-24795. [PubMed: 27658406]

50. Xue JF, et al. Assessment of carbon sustainability under different tillage systems in a double rice cropping system in Southern China. Int J Life Cycle Assess. 2014; 19:1581-1592.

51. Shen J, et al. Contrasting effects of straw and straw-derived biochar amendments on greenhouse gas emissions within double rice cropping systems. Agric Ecosyst Environ. 2014; 188:264-274.

52. Ma YC, et al. Net global warming potential and greenhouse gas intensity of annual rice - wheat rotations with integrated soil-crop system management. Agric Ecosyst Environ. 2013; 164:209219.

53. Zhang X, Xu X, Liu Y, Wang J, Xiong Z. Global warming potential and greenhouse gas intensity in rice agriculture driven by high yields and nitrogen use efficiency. Biogeosciences. 2016; 13:27012714. 
54. Yang B, et al. Mitigating net global warming potential and greenhouse gas intensities by substituting chemical nitrogen fertilizers with organic fertilization strategies in rice -wheat annual rotation systems in China: a 3-year field experiment. Ecol Eng. 2015; 81:289-297.

55. Zhang ZS, Guo LJ, Liu TQ, Li CF, Cao CG. Effects of tillage practices and straw returning methods on greenhouse gas emissions and net ecosystem economic budget in rice - wheat cropping systems in central China. Atmos Environ. 2015; 122:636-644.

56. Xiong Z, et al. Differences in net global warming potential and greenhouse gas intensity between major rice-based cropping systems in China. Sci Rep. 2015; 517774.

57. Xu Y, et al. Improved water management to reduce greenhouse gas emissions in no-till rapeseedrice rotations in Central China. Agric Ecosyst Environ. 2016; 221:87-98.

58. $\mathrm{Xu} \mathrm{Y,} \mathrm{et} \mathrm{al.} \mathrm{Effects} \mathrm{of} \mathrm{water-saving} \mathrm{irrigation} \mathrm{practices} \mathrm{and} \mathrm{drought} \mathrm{resistant} \mathrm{rice} \mathrm{variety} \mathrm{on}$ greenhouse gas emissions from a no-till paddy in the central lowlands of China. Sci Total Environ. 2015; 505:1043-1052. [PubMed: 25461105]

59. Yao Z, et al. Nitrous oxide and methane fluxes from a rice-wheat crop rotation under wheat residue incorporation and no-tillage practices. Atmos Environ. 2013; 79:641-649.

60. Xia L, Wang S, Yan X. Effects of long-term straw incorporation on the net global warming potential and the net economic benefit in a rice-wheat cropping system in China. Agric Ecosyst Environ. 2014; 197:118-127.

61. Zhang A, et al. Change in net global warming potential of a rice-wheat cropping system with biochar soil amendment in a rice paddy from China. Agric Ecosyst Environ. 2013; 173:37-45.

62. Zou J, Huang Y, Zong L, Zheng X, Wang Y. Carbon dioxide, methane, and nitrous oxide emissions from a rice-wheat rotation as affected by crop residue. Adv Atmos Sci. 2004; 21:691-698.

63. Zhou M, et al. Nitrous oxide and methane emissions from a subtropical rice-rapeseed rotation system in China: a 3-year field case study. Agric Ecosyst Environ. 2015; 212:297-309.

64. Yao Z, et al. Improving rice production sustainability by reducing water demand and greenhouse gas emissions with biodegradable films. Sci Rep. 2017; 739855.

65. Hijmans RJ, Cameron SE, Parra JL, Jones PG, Jarvis A. WorldClim - Global Climate Data: WorldClim Version 2. 2017. http://www.worldclim.org/version2

66. Hijmans RJ, Cameron SE, Parra JL, Jones PG, Jarvis A. WorldClim - Global Climate Data: Bioclimatic Variables. 2017. http://www.worldclim.org/bioclim

67. Heuzé V, Tran G, Hassoun P. Feedipedia: Rough Rice (Paddy Rice). Feedipedia, a programme by INRA, CIRAD, AFZ and FAO; 2015. https://www.feedipedia.org/node/226

68. Liang K, et al. Grain yield, water productivity and $\mathrm{CH} 4$ emission of irrigated rice in response to water management in south China. Agric Water Manag. 2016; 163:319-331.

69. Kreye $\mathrm{C}$, et al. Fluxes of methane and nitrous oxide in water-saving rice production in north China. Nutr Cycl Agroecosystems. 2007; 77:293-304.

70. Lu W, Cheng W, Zhang Z, Xin X, Wang X. Differences in rice water consumption and yield under four irrigation schedules in central Jilin Province China. Paddy Water Environ. 2016; 14:473-480.

71. Jin X, et al. Water consumption and water-saving characteristics of a ground cover rice production system. J Hydrol. 2016; 540:220-231.

72. Sun $\mathrm{H}$, et al. $\mathrm{CH}_{4}$ emission in response to water-saving and drought-resistancerice (WDR) and common rice varieties under different irrigation managements. Water, Air, Soil Pollut. 2016; 227:47.

73. Wang X, et al. The positive impacts of irrigation schedules on rice yield and water consumption: synergies in Jilin Province, Northeast China. Int J Agric Sustain. 2016; 14:1-12.

74. Xiong Y, Peng S, Luo Y, Xu J, Yang S. A paddy eco-ditch and wetland system to reduce non-point source pollution from rice-based production system while maintaining water use efficiency. Environ Sci Pollut Res. 2015; 22:4406-4417.

75. Shao G-C, et al. Effects of controlled irrigation and drainage on growth, grain yield and water use in paddy rice. Eur J Agron. 2014; 53:1-9.

76. Liu L, et al. Combination of site-specific nitrogen management and alternate wetting and drying irrigation increases grain yield and nitrogen and water use efficiency in super rice. F Crop Res. 2013; 154:226-235. 
77. Chen Y, Zhang G, Xu YJ, Huang Z. Influence of irrigation water discharge frequency on soil salt removal and rice yield in a semi-arid and saline-sodic area. Water (Switzerland). 2013; 5:578-592.

78. Ye Y, et al. Alternate wetting and drying irrigation and controlled-release nitrogen fertilizer in lateseason rice. Effects on dry matter accumulation, yield, water and nitrogen use. F Crop Res. 2013; 144:212-224.

79. Peng S, et al. Integrated irrigation and drainage practices to enhance water productivity and reduce pollution in a rice production system. Irrig Drain. 2012; 61:285-293.

80. Bell MJ, et al. Nitrous oxide emissions from fertilised UK arable soils: fluxes, emission factors and mitigation. Agric Ecosyst Environ. 2015; 212:134-147.

81. Bell MJ, , et al. Agricultural Greenhouse Gas Inventory Research Platform - InveN2Ory: Fertiliser Experimental Site in East Lothian, 2011. Version:1 [dataset]. Freshwater Biological Association; 2017.

82. Cardenas LM, Webster C, Donovan N. Agricultural Greenhouse Gas Inventory Research Platform InveN2Ory: Fertiliser Experimental Site in Bedfordshire, 2011. Version:1 [dataset]. Freshwater Biological Association; 2017.

83. Williams JR, Balshaw H, Bhogal A, Kingston H, Paine F, Thorman RE. Agricultural Greenhouse Gas Inventory Research Inventory Research Platform - InveN2Ory: Fertiliser Experimental Site in Herefordshire, 2011. Version:1 [dataset]. Freshwater Biological Association; 2017.

84. Goulding KWT, Poulton PR, Webster CP, Howe MT. Nitrate leaching from the Broadbalk Wheat Experiment, Rothamsted, UK, as influenced by fertilizer and manure inputs and the weather. Soil Use Manag. 2000; 16:244-250.

85. Cardoso AS, et al. Impact of the intensification of beef production in Brazil on greenhouse gas emissions and land use. Agric Syst. 2016; 143:86-96.

86. de Figueiredo EB, et al. Greenhouse gas balance and carbon footprint of beef cattle in three contrasting pasture-management systems in Brazil. J Clean Prod. 2017; 142:420-431.

87. Dick M, Abreu Da Silva M, Dewes H. Life cycle assessment of beef cattle production in two typical grassland systems of southern Brazil. J Clean Prod. 2015; 96:426-434.

88. Florindo TJ, de Medeiros Florindo GIB, Talamini E, da Costa JS, Ruviaro CF. Carbon footprint and Life Cycle Costing of beef cattle in the Brazilian midwest. J Clean Prod. 2017; 147:119-129.

89. Mazzetto AM, Feigl BJ, Schils RLM, Cerri CEP, Cerri CC. Improved pasture and herd management to reduce greenhouse gas emissions from a Brazilian beef production system. Livest Sci. 2015; 175:101-112.

90. Pashaei Kamali F, et al. Environmental and economic performance of beef farming systems with different feeding strategies in southern Brazil. Agric Syst. 2016; 146:70-79.

91. Ruviaro CF, De Léis CM, Lampert VDN, Barcellos JOJ, Dewes H. Carbon footprint in different beef production systems on a southern Brazilian farm: a case study. J Clean Prod. 2015; 96:435443.

92. Ruviaro CF, et al. Economic and environmental feasibility of beef production in different feed management systems in the Pampa biome, southern Brazil. Ecol Indic. 2016; 60:930-939.

93. Dick M, Da Silva MA, Dewes H. Mitigation of environmental impacts of beef cattle production in southern Brazil - evaluation using farm-based life cycle assessment. J Clean Prod. 2015; 87:58-67.

94. Lesnoff M. DynMod: a Tool for Demographic Projections of Tropical Livestock Populations Under Microsoft Excel, User's Manual - Version 1. CIRAD, Montpelier, Cedex; ILRI, Nairobi, Kenya: 2008.

95. Broom DM, Galindo FA, Murgueitio E. Sustainable, efficient livestock production with high biodiversity and good welfare for animals. Proc R Soc B. 2013; 28020132025.

96. Junior CC, et al. Brazilian beef cattle feedlot manure management: a country survey. J Anim Sci. 2013; 91:1811-1818. [PubMed: 23345562]

97. Garnsworthy PC. The environmental impact of fertility in dairy cows: a modelling approach to predict methane and ammonia emissions. Anim Feed Sci Technol. 2004; 112:211-223.

98. Collins AL, Zhang Y. Exceedance of modern 'background' fine-grained sediment delivery to rivers due to current agricultural land use and uptake of water pollution mitigation options across England and Wales. Environ Sci Policy. 2016; 61:61-73. 
99. Chadwick D, et al. Manure management: implications for greenhouse gas emissions. Anim Feed Sci Technol. 2011; 166-167:514-531.

100. DEFRA. Organic Dairy Cows: Milk Yield and Lactation Characteristics in Thirteen Established Herds and Development of a Herd Simulation Model for Organic Milk Production. Project Report OF0170. DEFRA; 2000. http://randd.defra.gov.uk/Default.aspx? Menu=Menu $\&$ Module $=$ More $\&$ Location $=$ None $\&$ Completed $=0 \&$ ProjectID $=8431$

101. Wilkinson JM. Re-defining efficiency of feed use by livestock. Animal. 2011; 5:1014-1022. [PubMed: 22440097]

102. Webb J, Audsley E, Williams A, Pearn K, Chatterton J. Can UK livestock production be configured to maintain production while meeting targets to reduce emissions of greenhouse gases and ammonia? J Clean Prod. 2014; 83:204-211.

103. de Ponti T, Rijk B, van Ittersum MK. The crop yield gap between organic and conventional agriculture. Agric Syst. 2012; 108:1-9.

104. Gerber P, Vellinga T, Opio C, Henderson B, Steinfeld H. Greenhouse Gas Emissions from the Dairy Sector: A Life Cycle Assessment. Food and Agriculture Organization of the United Nations; Rome: 2010. http://www.fao.org/docrep/012/k7930e/k7930e00.pdf

105. Brown K, , et al. UK Greenhouse Gas Inventory, 1990 to 2010: Annual Report for Submission under the Framework Convention on Climate Change. DEFRA; 2012. https://uk-air.defra.gov.uk/ assets/documents/reports/cat07/1204251149_ukghgi-90-10_main_chapters_issue2_print_v1.pdf

106. Misselbrook TH, Sutton MA, Scholefield D. A simple process-based model for estimating ammonia emissions from agricultural land after fertilizer applications. Soil Use Manag. 2006; 20:365-372.

107. Misselbrook TH, Gilhespy SL, Cardenas LM, Williams J, Dragosits U. Inventory of Ammonia Emissions from UK Agriculture 2015: DEFRA Contract Report (SCF0102). DEFRA; 2016. https://uk-air.defra.gov.uk/assets/documents/reports/ cat07/1702201346_nh3inv2015_Final_1_30092016.pdf

108. Vellinga TV, , et al. Methodology Used in FeedPrint: a Tool Quantifying Greenhouse Gas Emissions of Feed Production and Utilization, Report 674. Wageningen UR Livestock Research; Lelystad, The Netherlands: 2013.

109. Anthony S, Quinn P, Lord E. Catchment scale modelling of nitrate leaching. Asp Appl Biol. 1996; 46:23-32.

110. Wang L, et al. The changing trend in nitrate concentrations in major aquifers due to historical nitrate loading from agricultural land across England and Wales from 1925 to 2150. Sci Total Environ. 2016; 542:694-705. [PubMed: 26546765]

111. Davison PS, Lord EI, Betson MJ, Strömqvist J. PSYCHIC - A process-based model of phosphorus and sediment mobilisation and delivery within agricultural catchments. Part 1: Model description and parameterisation. J Hydrol. 2008; 350:290-302.

112. Koponen K, Soimakallio S. Foregonecarbon sequestration due to land occupation - the case of agro-bioenergy in Finland. Int J Life Cycle Assess. 2015; 20:1544-1556.

113. Guo LB, Gifford RM. Soil carbon stocks and land use change: a meta analysis. Glob Chang Biol. 2002; 8:345-360. 

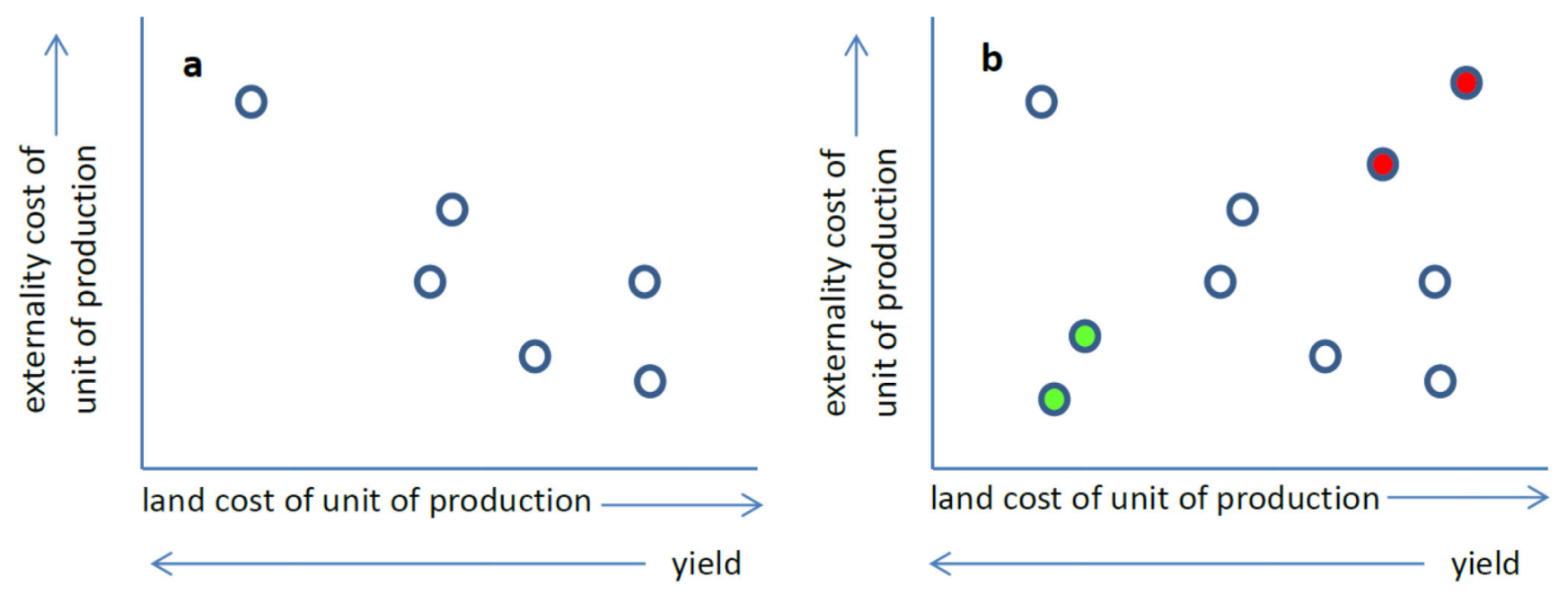

Fig. 1. Framework for exploring how different environmental costs compare across alternative production systems.

a, Hypothetical plot of externality cost $v s$ land cost of different, potentially interchangeable production systems (blue circles) in a given farming sector. In this example the data suggest a trade-off between externality and land costs across different systems. b, This example reveals a more complex pattern, with additional systems (in green and red circles) that are low or high in both costs. 

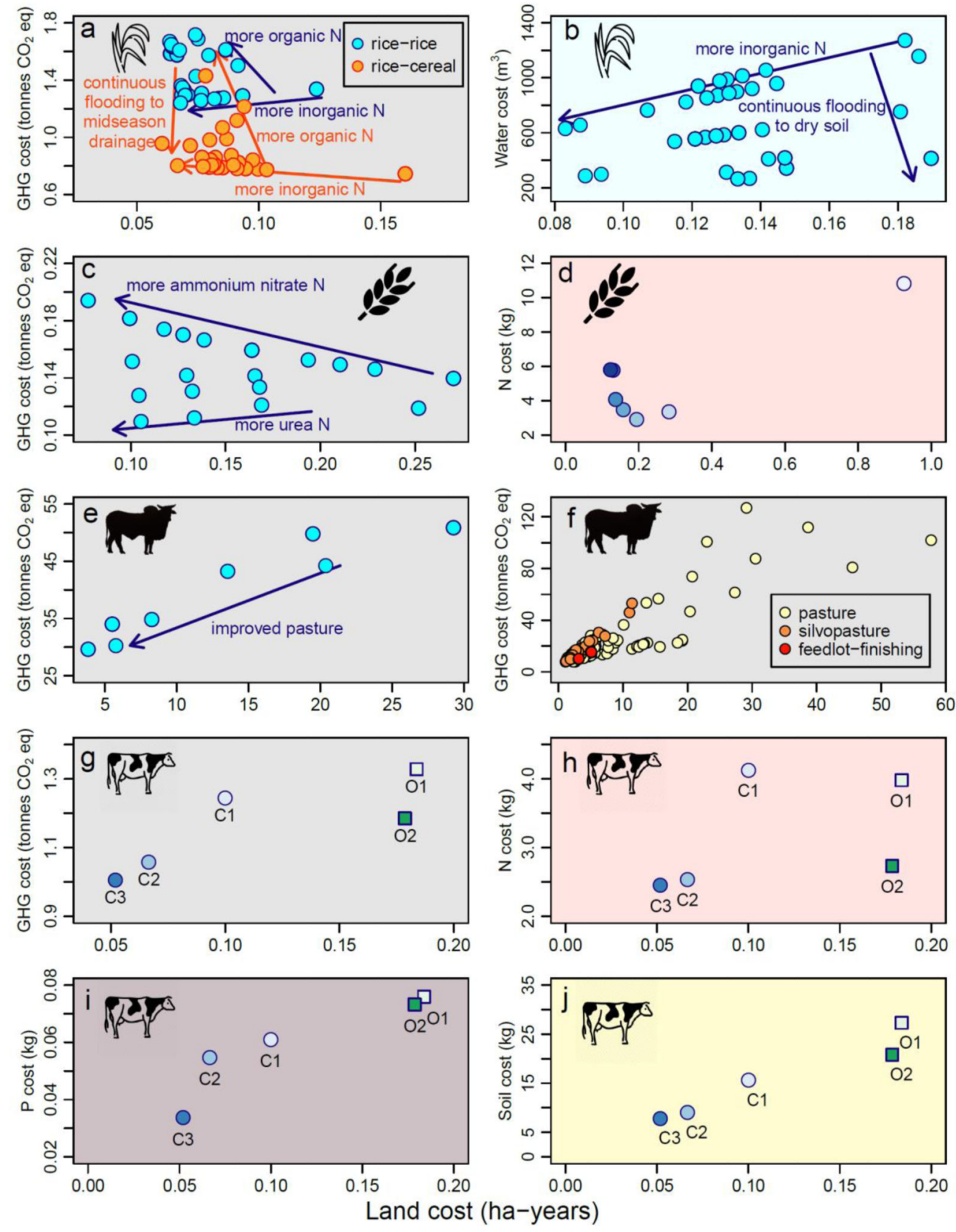

Fig. 2. Externality costs of alternative production systems against land cost for five externalities in four agricultural sectors.

All costs are expressed per tonne of production (so land cost, for instance, is in ha-years/ tonne- i.e. the inverse of yield). Different externalities are indicated by background shading (grey $=$ GHG emissions, blue $=$ water use, pink $=\mathrm{N}$ emissions, purple $=\mathrm{P}$ emissions, buff $=$ soil loss), and different sectors (Asian paddy rice, European wheat, Latin American beef, European dairy) are shown by icons. Points on plots derived from multi-site experiments (a, b, c) and LCAs (e) show values for systems adjusted for site and study effects via GLMMs 
of land cost and externality cost (for 95\% confidence intervals, see Supplementary Fig. 1), while arrows show management practices with statistically-significant effects (whose 95\% confidence intervals do not overlap zero in the GLMMs; Methods). In d (wheat and N emissions), progressively darker circles depict increasing nitrate application rate $(0,48,96$, 144, 192, 240 and $288 \mathrm{~kg}$ N/ha-year). In $\mathbf{f}$ (beef and GHG emissions, estimated by RUMINANT), different colours show different system types. In g-j (dairy and four externalities), circles and squares show results for conventional and organic systems, respectively (detailed in Supplementary Table 4). Spearman's rank correlation coefficients (p-values) are a. rice-rice: -0.51 (0.002), rice-cereal: $-0.36(0.06)$, b. $0.19(0.26)$, c. -0.34 (0.14), d. $-0.21(0.66)$, e. 0.95 (0.001), f. $0.83(<0.001)$, g. $0.90(0.08)$, h. $0.70(0.23)$, i. 1.00 $(0.02)$ and j. $1.00(0.02)$. Note that these correlation coefficients do not necessarily reflect non-linear relationships (e.g., d) accurately. 


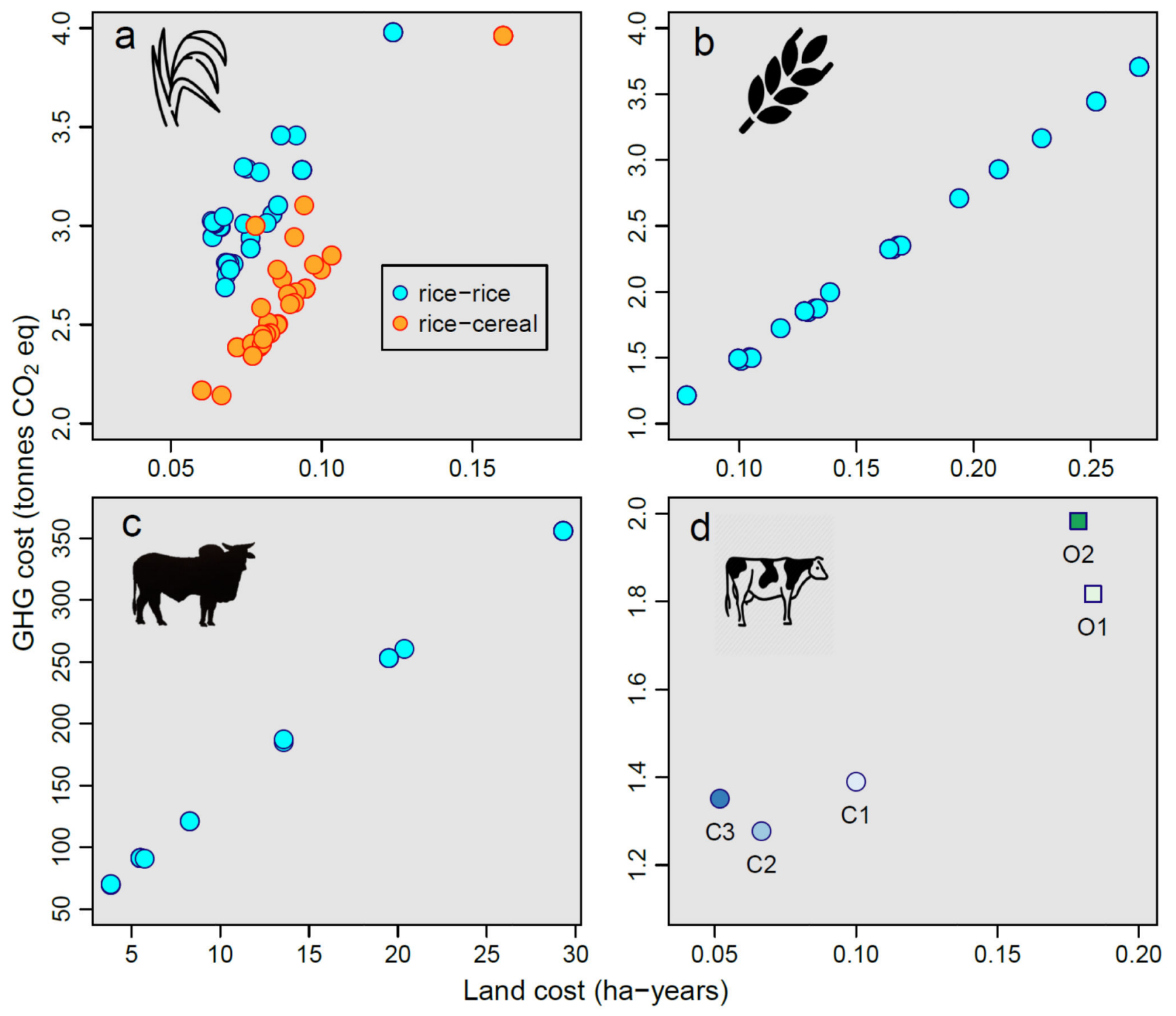

Fig. 3. Overall GHG cost against land cost of alternative systems in each sector, including the GHG opportunity costs of land under farming.

Y-axis values are the sum of GHG emissions from farming activities (plotted in Figs. 2 a, c, $\mathrm{e}, \mathrm{g}$ ) and the forgone sequestration potential of land maintained under farming and thus unable to revert to natural vegetation (Methods). All costs are expressed per tonne of production. Notation as in Fig. 2. Spearman's rank correlation coefficients (p-values) are a. rice-rice: $0.40(0.017)$, rice-cereal: $0.80(<0.001)$, b. $0.99(<0.001)$, c. $0.98(<0.001)$ and d. $0.80(0.13)$. 